\title{
PENGARUH PENGGUNAAN MODUL DAN METODE CERAMAH TERHADAP HASIL BELAJAR MATEMATIKA PADA PESERTA DIDIK KEJAR PAKET B DI KABUPATEN BARRU
}

\section{Djonny Pabisa}

IPDN Kampus Sulawesi Utara, Indonesia

Email: terapi.28128@gmail.com

\begin{abstract}
Abstrak
Penelitian ini menggunakan pendekatan penelitian kuantitatif dengan menggunakan model treatment posttest-only control group design. Populasi adalah peserta didik kejar Paket B yang dibina PPLS dan SKB Kabupaten Barru. Penentuan sampel menggunakan teknik purposive sampling. Penetapan kelompok yang diteliti diambil dari anggota sampel dengan menggunakan teknik simple random sampling. Pengumpulan data dilakukan dengan menggunakan tes hasil belajar matematika Paket B kelas II dan data hasil pengukuran dianalisis dengan menggunakan teknik analisis statistik deskriptif dan teknik analisis statistik inferensial, yaitu anavar satu arah dan uji lanjut scheffe. Hasil penelitian menunjukkan bahwa: (1) hasil belajar matematika Paket B kelas II untuk kelompok peserta didik yang diajar dengan menggunakan modul maupun yang diajar dengan menggunakan metode ceramah masing-masing berada pada kualifikasi sedang. Hasil belajar matematika Paket B kelas II untuk kelompok peserta didik yang diajar dengan menggunakan metode konvensional berada pada kualifikasi rendah dan (2) terdapat perbedaan hasil belajar matematika Paket B kelas II antara kelompok peserta didik yang diajar dengan menggunakan modul, metode ceramah, dan metode konvensional.
\end{abstract}

Kata Kunci: modul; metode ceramah; hasil belajar; paket B

\section{Abstract}

This study uses a quantitative research approach using a posttest-only control group design treatment model. The population is the students of chase Package $B$ who are fostered by PPLS and SKB Barru Regency. Determination of the sample using the purposive sampling technique. The determination of the studied group was taken from the sample members using a simple random sampling technique. Data was collected using the Package B class II mathematics learning outcomes test and the measurement data were analyzed using descriptive statistical analysis techniques and inferential statistical analysis techniques, namely one-way anavar and scheffe advanced test. The results showed that: (1) the learning outcomes of Package B class II mathematics for groups of students who were taught using the module and those taught using the lecture method were in moderate qualifications. The results of learning mathematics in Package B class II for groups of students taught using

$\begin{array}{ll}\text { How to cite: } & \text { Pabisa. Djonny (2021) Pengaruh Penggunaan Modul dan Metode Ceramah terhadap Hasil Belajar } \\ & \text { Matematika pada Peserta Didik Kejar Paket B di Kabupaten Barru. Syntax Literate: Jurnal Ilmiah } \\ & \text { Indonesia, 6(2) } \\ \text { E-ISSN: } & 2548-1398 \\ \text { Published by: } & \text { Ridwan Institute }\end{array}$


conventional methods are in low qualifications and (2) there are differences in learning outcomes for Mathematics in Package B class II between groups of students taught using modules, lecture methods, and conventional methods.

Keywords: module; lecture method; learning outcomes; package B

Received: 2021-10-20; Accepted: 2021-11-05; Published: 2021-11-20

\section{Pendahuluan}

Pendidikan non formal atau lebih dikenal dengan sebutan pendidikan luar sekolah diselenggarakan bagi masyarakat yang memerlukan layanan pendidikan yang berfungsi sebagai pengganti, penambah, dan/atau pelengkap pendidikan formal dalam rangka mendukung pendidikan sepanjang hayat. Pendidikan luar sekolah berfungsi mengembangkan potensi peserta didik dengan penekanan pada penguasaan pengetahuan dan keterampilan fungsional serta pengembangan sikap dan kepribadian profesional. Peserta didik pendidikan luar sekolah adalah warga masyarakat yang tidak pernah sekolah, putus sekolah, anak usia dini, dan pencari kerja yang perlu bekal keterampilan dan ingin meningkatkan kemampuan atau keterampilan profesionalnya untuk meningkatkan kualitas hidupnya di masa depan (Depdikbud, 1995). Pendidikan luar sekolah dapat dikelompokkan menjadi tiga bidang pendidikan yang integral (Depdiknas, 2000), yaitu: (1) pendidikan keaksaraan, (2) pendidikan dasar, dan (3) pendidikan berkelanjutan.

Pendidikan kesetaraan pada pendidikan luar sekolah khususnya pendidikan dasar (paket A setara SD dan Paket B setara SMP) menggunakan bahan ajar yang disusun dalam bentuk modul-modul berdasarkan tingkat kesetaraan dari setiap mata pelajaran. Proses pembelajaran pada Kejar Paket B seharusnya dapat dibedakan dengan proses pendidikan yang berlangsung pada jalur pendidikan formal, meskipun kurikulumnya dianggap setara dengan kurikulum SMP (Depdiknas, 2003a). Penggunaan modul dalam pembelajaran tidak terlepas dari sistem tutorial yang dianut oleh pendidikan luar sekolah yang pada dasarnya memberikan kesempatan kepada peserta didik untuk dapat belajar sendiri sesuai dengan kemampuan belajarnya masing-masing dan menempatkan peran tutor sebatas melaksanakan bimbingan, memberi bantuan, mengarahkan, dan menggerakkan peserta didik (Ahmadi \& Prasetya, 1997).

Kenyataan di lapangan menunjukkan bahwa penggunaan modul dalam pengajaran pada Kejar Paket B masih sangat minimal dan lebih banyak didominasi oleh pengajaran dengan menggunakan metode ceramah. Pengajaran program paket B secara substansial harus menggunakan modul yang disediakan, ternyata lebih banyak dilakukan dengan menggunakan metode ceramah (Depdiknas, 2003b). Kenyataan ini sejalan dengan hasil penelitian yang dilakukan (Rifa'i, 2002) yang menemukan bahwa sekitar 75 persen peserta didik paket B di Propinsi Jawa Tengah menyukai metode ceramah digunakan sebagai metode pengajaran pada program paket B, sedangkan sisanya 25 persen menyukai metode kerja kelompok. (Utsman, 2016) menemukan fakta dalam penelitian yang dilakukannya, bahwa metode yang digunakan tutor dalam proses pembelajaran 
paket B di Jawa Tengah secara umum masih menggunakan metode ceramah. Belajar dengan sistem modul sulit untuk dilaksanakan meskipun modul yang tersedia cukup. Penggunaan metode ceramah ini dilakukan karena sebagian besar tutor berasal dari guru sekolah formal, sehingga belum banyak mengenal metode-metode pengajaran yang sering diterapkan pada pendidikan luar sekolah. Selain itu, pengelola kegiatan belajar paket B dalam proses pembelajaran secara umum menggunakan metode dan teknik yang sama dengan pembelajaran pada sekolah-sekolah formal dan mereka kurang memahami tentang metode dan proses pembelajaran pada program Kejar Paket B.

Penggunaan metode ceramah potensial terjadi dalam pengelolaan kegiatan belajar paket B disebabkan juga oleh persoalan klasik pada pendidikan luar sekolah yang sering terabaikan, yaitu: (1) modul-modul pelajaran paket B masih dibiarkan menumpuk di gudang buku Dinas Pendidikan dan Sanggar Kegiatan Belajar (SKB), (2) para tutor dibiarkan mengajar matematika hanya dengan metode ceramah, walaupun modul sudah dimiliki, (3) kurangnya peran pengelola dan tutor dalam mengoptimalkan pemanfaatan modul oleh peserta didik sebagai upaya menunjang peningkatan kemampuan belajar mereka, (4) pelatihan-pelatihan yang diselenggarakan untuk para tutor masih belum mampu memberikan bantuan dalam mengatasi kesulitan penggunaan modul paket $\mathrm{B}$, dan (5) mata pelajaran seperti matematika banyak diajarkan oleh Pamong Belajar atau tutor yang kurang kompeten di bidangnya.

Pengajaran dengan menggunakan modul secara teori memiliki banyak perbedaan bila dibandingkan dengan bentuk pengajaran menggunakan metode ceramah (Nasution, 2000). Adanya perbedaan tersebut diduga juga memberi indikasi adanya perbedaan pada hasil belajar peserta didik pada program paket $\mathrm{B}$.

Berdasarkan uraian itu, permasalahan dalam penelitian ini dapat dirumuskan sebagai berikut: (1) Bagaimana gambaran hasil belajar matematika peserta didik yang diajar matematika paket B dengan menggunakan modul, metode ceramah, dan metode konvensional pada Kejar Paket B kelas II di Kabupaten Barru? dan (2) apakah terdapat perbedaan hasil belajar matematika peserta didik kelompok yang diajar matematika paket B dengan menggunakan modul, metode ceramah, dan metode konvensional?.

Tujuan yang ingin dicapai dalam penelitian ini adalah: (1) Untuk mendapatkan gambaran hasil belajar matematika peserta didik yang diajar matematika paket B dengan menggunakan modul, metode ceramah, dan metode konvensional pada Kejar Paket B kelas II di Kabupaten Barru dan (2) untuk mengungkap ada atau tidak ada perbedaan hasil belajar matematika peserta didik kelompok yang diajar matematika paket B dengan menggunakan modul, metode ceramah, dan metode konvensional pada Kejar Paket B kelas II di Kabupaten Barru.

Manfaat yang diperoleh dari hasil penelitian ini adalah: (1) dapat membantu tutor untuk menetapkan pilihan yang tepat dalam penggunaan metode pembelajaran matematika pada Kejar Paket B guna meningkatkan hasil belajar matematika peserta didik, (2) membantu tutor dan pelaksana teknis pendidikan luar sekolah lainnya untuk dapat meningkatkan efektivitas dan efisiensi pengelolaan sistem pembelajaran matematika paket B dengan menggunakan modul, metode ceramah, atau metode 
konvensional pada Kejar Paket B, (3) sebagai bahan masukan bagi penyelenggara pelatihan calon tutor dan penyelenggara program paket B untuk dapat meningkatkan sikap, pengetahuan, dan keterampilan di dalam pengelolaan, pelatihan, dan pembelajaran yang menggunakan modul, metode ceramah, dan metode konvensional, (4) sebagai bahan masukan bagi semua pihak yang berkecimpung pada bidang pendidikan luar sekolah untuk dapat memilih pola pengajaran yang tepat, sehingga dapat membantu meningkatkan kualitas lulusan paket B, dan (5) sebagai bahan masukan dalam usaha meningkatkan pengelolaan sistem pembelajaran program paket B oleh Sub Dinas Pendidikan Luar Sekolah Dinas Pendidikan dan Kebudayaan, Sanggar Kegiatan Belajar, penilik luar sekolah, tenaga lapangan pendidikan masyarakat, dan mitra teknis pendidikan luar sekolah lainnya yang ada di Kabupaten Barru.

\section{Metode Penelitian}

Penelitian dilaksanakan di Kabupaten Barru, yaitu pada Kejar Paket B yang dibina oleh Dinas Pendidikan dan Sanggar Kegiatan Belajar (SKB) dengan jenis penelitian kuantitatif yang memakai model treatment posttest-only control group design. Variabelvariabel yang diteliti adalah: (1) metode pengajaran sebagai variabel bebas terdiri atas: penggunaan modul diberi simbol X1, metode ceramah diberi simbol X2, dan metode konvensional diberi simbol X3 dan (2) hasil belajar matematika Paket B sebagai variabel terikat terdiri atas: hasil belajar dengan menggunakan modul diberi simbol Y1, metode ceramah diberi simbol Y2, dan metode konvensional diberi simbol Y3. Populasi dalam penelitian adalah seluruh peserta didik pada Kejar Paket B yang sampai penelitian ini dilaksanakan masih berstatus aktif mengikuti kegiatan belajar mengajar. Penentuan sampel dilakukan dengan menggunakan teknik purposive sampling, selanjutnya pengambilan anggota sampel mempergunakan teknik acak sederhana.

Dalam penelitian ini digunakan instrumen tes hasil belajar matematika Paket B yang disusun sendiri oleh peneliti dan sebelum digunakan terlebih dahulu dilakukan ujicoba. Berdasarkan hasil ujicoba dapat diketahui bahwa soal yang dinyatakan valid sebanyak 32 butir soal dan soal yang dinyatakan tidak valid sebanyak 16 butir soal dengan nilai reliabilitas sebesar 0,848 .

Data hasil pengukuran dianalisis dengan menggunakan teknis analisis statistik deskriptif dan teknik analisis statistik inferensial, yaitu anavar satu arah dan uji lanjut scheffe.

\section{Hasil dan Pembahasan}

kelompok yang diajar dengan menggunakan modul mendapatkan skor dengan kualifikasi rendah, sedangkan peserta didik yang mendapatkan skor dengan kualifikasi sedang sebanyak 92 persen. Skor terendah yang diperoleh peserta didik adalah 9 dan skor tertinggi adalah 20. Rata-rata (mean) skor data hasil pengukuran adalah 15,75. Skor rata-rata yang diperoleh menunjukkan bahwa hasil belajar matematika Paket B peserta didik tergolong berada pada kualifikasi sedang. Sebanyak 33 persen peserta 
didik yang memperoleh nilai di bawah rata-rata dan sebanyak 50 persen peserta didik yang memperoleh nilai di atas rata-rata.

Sebesar 25 persen peserta didik pada kelompok yang diajar dengan menggunakan metode ceramah mendapatkan skor dengan kualifikasi rendah, peserta didik yang mendapatkan nilai dengan kualifikasi sedang sebanyak 50 persen, dan sebanyak 25 persen peserta didik yang mendapatkan skor dengan kualifikasi tinggi. Skor terendah yang diperoleh peserta didik pada kelompok yang diajar dengan menggunakan metode ceramah adalah 9 dan skor tertinggi adalah 23. Skor Rata-rata (mean) data hasil pengukuran adalah 15,5. Skor rata-rata yang diperoleh menunjukkan bahwa hasil belajar matematika Paket B tergolong berada pada kualifikasi sedang. Peserta didik yang memperoleh nilai di bawah rata-rata sekitar 58 persen dan peserta didik yang memperoleh nilai di atas rata-rata sebanyak 33 persen.

Skor rata-rata hasil belajar matematika Paket B kelas II pada kedua kelompok eksperimen secara statistik dinyatakan tidak berbeda (masing-masing berada pada kualifikasi sedang) diduga sebagai akibat: (1) tutor yang mengajar berlatar belakang pendidikan matematika (S1 matematika) sehingga dapat dimengerti bila dalam proses belajar mengajar, materi pelajaran dapat diajarkan secara tuntas dan (2) tutor yang mengajar pada kedua kelompok eksperimen menguasai dengan baik penggunaan modul dan penggunaan metode ceramah dalam pengajaran matematika Paket B kelas II. Pada penggunaan metode ceramah, peserta didik menunjukkan keaktifan dengan ikut serta bersama-sama tutor dalam menjelaskan atau menyebutkan sesuatu. Keaktifan itu juga ditunjukkan dengan keberanian anak maju ke depan untuk mengerjakan soal-soal yang ditanyakan tutor di papan tulis. Pada penggunaan modul, Peserta didik sangat baik dalam merespon petunjuk-petunjuk yang diberikan tutor. Peserta didik tidak begitu mempersoalkan bentuk penampilan modul. Peserta didik hanya sering mengeluhkan adanya kesalahan-kesalahan jawaban pada contoh-contoh soal dan pada kunci jawaban. Keluhan ini selalu disampaikan kepada peneliti selama kegiatan belajar mengajar berlangsung dan peneliti mengajak peserta didik untuk sama-sama membetulkannya.

Sebanyak 60 persen peserta didik pada kelompok yang diajar dengan menggunakan metode konvensional mendapatkan skor dengan kualifikasi rendah, sedangkan peserta didik yang mendapatkan skor dengan kualifikasi sedang sebesar 40 persen. Skor terendah yang diperoleh peserta didik adalah 4 dan skor tertinggi adalah 15. Skor rata-rata (mean) data hasil pengukuran adalah 9,6. Skor rata-rata yang diperoleh menunjukkan bahwa hasil belajar matematika Paket B tergolong berada pada kualifikasi rendah. Peserta didik yang memperoleh nilai di bawah rata-rata sekitar 47 persen dan peserta didik yang memperoleh nilai di atas rata-rata sebanyak 20 persen.

Hasil belajar yang rendah ini diduga sebagai akibat: (1) kemampuan peserta didik yang memang lemah dalam menyerap materi pelajaran yang diajarkan oleh tutor, sehingga berdampak pada sulitnya peserta didik dalam mengembangkan materi pelajaran yang telah diterimanya, (2) materi pelajaran yang diajarkan oleh tutor tidak tuntas dan tutor matematika pada kelompok kontrol belum terlatih dan belum memiliki keterampilan yang baik dalam memilih dan menggunakan berbagai metode secara 
bervariasi dalam mengajarkan matematika Paket B kelas II, dan (3) latar belakang pendidikan tutor yang tidak sejalan dengan mata pelajaran yang diajarkan dan tidak dimilikinya buku acuan atau bahan bacaan yang dapat dijadikan sebagai pegangan bagi peserta didik untuk dapat mengulang, berlatih, dan mengembangkan materi pelajaran yang telah dipelajarinya. Peserta didik bergantung sepenuhnya pada bahan pelajaran yang telah diajarkan secara terbatas oleh tutor.

Pengolahan data hasil pengukuran menunjukkan bahwa nilai $F_{\text {hitung }}$ sebesar 10,7 ternyata lebih besar dari nilai $F_{\text {tabel }}$ pada $\alpha=0,05$ atau $F_{(0,95 ; 2: 36)}=3,26$ bahkan sampai pada nilai $F_{\text {tabel }}$ dengan $\alpha=0,01$ atau $\mathrm{F}_{(0,99 ; 2: 36)}=5,25$. Hal ini berarti bahwa terdapat perbedaan yang sangat signifikan antara hasil belajar matematika Paket B pada ketiga kelompok peserta didik yang diajar matematika Paket B dengan menggunakan modul, metode ceramah, dan metode konvensional pada Kejar Paket B kelas II di Kabupaten Barru Propinsi Sulawesi Selatan. Dengan kata lain, $\mathrm{H}_{0}$ ditolak dan $\mathrm{H}_{1}$ diterima.

Hasil penghitungan untuk menentukan signifikansi perbedaan hasil belajar dari ketiga kelompok dengan menggunakan Scheffe test dapat dilihat pada Tabel di bawah ini:

Tabel 1

Hasil hitung Scheffe test

\begin{tabular}{lccccc}
\hline & \multicolumn{2}{c}{$\mathrm{F}_{\text {tabel }}=\mathrm{F}_{(1-\alpha ; 2 ; 38)}$} & \multicolumn{2}{c}{$\mathrm{F}^{\prime}=(\mathrm{k}-1) \mathrm{F}_{\text {tabel }}$} & \multirow{2}{*}{ Kelompok } \\
\cline { 2 - 5 } & $\alpha=$ & $\alpha=$ & $\alpha=$ & $\alpha=$ & \multirow{2}{*}{$\mathrm{F}_{\text {hitung }}$} \\
& 0,05 & 0,01 & 0,05 & 0,01 & \\
\hline Modul VS Ceramah & 3,25 & 5,21 & 6,50 & 10,42 & 0,0237 \\
Modul VS Konven-sional & 3,25 & 5,21 & 6,50 & 10,42 & $\left.15,9183^{*}\right)$ \\
& & & & & \\
Ceramah VS Konvensional & 3,25 & 5,21 & 6,50 & 10,42 & $\left.14,6504^{*}\right)$ \\
\hline
\end{tabular}

Keterangan: $\mathrm{k}=3 ; \quad *$ ) sangat signifikan

Berdasarkan Tabel tersebut, menunjukkan bahwa: (1) pengajaran matematika Paket $\mathrm{B}$ dengan menggunakan modul memberi pengaruh yang sama baiknya (tidak berbeda) dengan pengajaran matematika Paket $B$ yang menggunakan metode ceramah pada Kejar Paket B kelas II di Kabupaten Barru (karena $F_{\text {hitung }}$ lebih kecil dari F'), (2) pengajaran matematika Paket B dengan menggunakan modul memberi pengaruh yang lebih baik (sangat signifikan) bila dibandingkan dengan pengajaran matematika Paket B yang menggunakan metode konvensional pada Kejar Paket B kelas II di

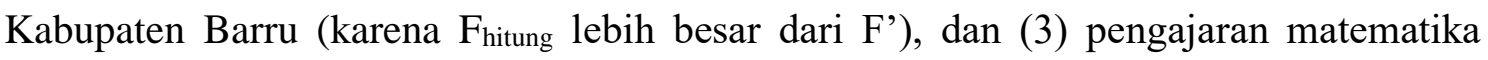
Paket $\mathrm{B}$ dengan menggunakan metode ceramah memberi pengaruh yang lebih baik (sangat signifikan) bila dibandingkan dengan pengajaran matematika Paket B yang menggunakan metode konvensional pada Kejar Paket B kelas II di Kabupaten Barru (karena $F_{\text {hitung }}$ lebih besar dari F'). 

pada Peserta Didik Kejar Paket B di Kabupaten Barru

\section{Kesimpulan}

Berdasarkan hasil penelitian dan pembahasan yang telah diuraikan, dapat dikemukakan kesimpulan sebagai berikut: (1) hasil belajar matematika Paket B kelas II untuk kelompok peserta didik yang diajar dengan menggunakan modul dan hasil belajar kelompok peserta didik yang diajar dengan menggunakan metode ceramah masingmasing berada pada kualifikasi sedang. Hasil belajar matematika Paket B kelas II untuk kelompok peserta didik yang diajar dengan menggunakan metode konvensional berada pada kualifikasi rendah, (2) terdapat perbedaan antara hasil belajar matematika Paket B kelas II pada ketiga kelompok peserta didik yang diajar dengan menggunakan modul, metode ceramah, dan metode konvensional. Hasil belajar kelompok peserta didik yang diajar dengan menggunakan modul lebih baik bila dibandingkan dengan hasil belajar kelompok peserta didik yang diajar dengan menggunakan metode konvensional. Hal ini berarti bahwa pengajaran matematika Paket B dengan menggunakan modul memberi pengaruh yang lebih baik bila dibandingkan dengan pengajaran matematika Paket B yang menggunakan metode konvensional. Hasil belajar kelompok peserta didik yang diajar dengan menggunakan metode ceramah lebih baik bila dibandingkan dengan hasil belajar kelompok peserta didik yang diajar dengan metode konvensional. Hal ini berarti bahwa pengajaran matematika Paket B dengan menggunakan metode ceramah memberi pengaruh yang lebih baik bila dibandingkan dengan pengajaran matematika Paket B yang menggunakan metode konvensional. Hasil belajar kelompok peserta didik yang diajar dengan menggunakan modul dianggap sama baiknya dengan hasil belajar kelompok peserta didik yang diajar dengan menggunakan metode ceramah, walaupun skor rata-rata dari kelompok peserta didik yang diajar dengan menggunakan modul lebih besar dari skor rata-rata dari kelompok peserta didik yang diajar dengan menggunakan metode ceramah. 
Djonny Pabisa

\section{BIBLIOGRAFI}

Ahmadi, Abu, \& Prasetya, Joko Tri. (1997). Strategi Belajar Mengajar, Bandung: CV. Pustaka Setia. Google Scholar

Depdikbud. (1995). Program Pendidikan Luar Sekolah. Jakarta: Dirjen PLSPO. Google Scholar

Depdiknas. (2000). Rencana Strategis Pembangunan Bidang Pendidikan Luar Sekolah Tahun 2000-2004. Retrieved from http://www.depdiknas.go.id Google Scholar

Depdiknas. (2003a). Pedoman Penyelenggaraan Program Paket B Setara SLTP (Diktentis, ed.). Jakarta. Google Scholar

Depdiknas. (2003b). Pembelajaran dan Pengajaran Kontekstual. Jakarta: Dikdasmen. Google Scholar

Nasution, Sorimuda. (2000). Berbagai pendekatan dalam proses belajar dan mengajar. Google Scholar

Rifa'i, Ahmad. (2002). Penyelenggaraan Wajib Belajar 9 Tahun Bagi Anak-Anak Kurang Beruntung di Jawa Tengah. Google Scholar

Utsman, Utsman. (2016). Evaluasi Potensi Kelompok Belajar Paket B Untuk Menunjang Wajib Belajar 9 Tahun (Studi pada Beberapa Daerah Tingkat II di Jawa Tengah). Journal of Nonformal Education, 2(2). Google Scholar

\section{Copyright holder:}

Djonny Pabisa (2021)

First publication right:

Syntax Literate: Jurnal Ilmiah Indonesia

This article is licensed under: 